\section{Synthesis of Sexual Hormone Glycuronides}

THE importance of glycuronic acid lies in its property of condensing with hydroxylic compounds to produce the so-called coupled glycuronic acids. In this way these substances become soluble in water and therefore also in urine. From the researches of Cohen and Marrian', Cohen, Marrian and Odell'², as well as those of Venning and Browne ${ }^{3}$, glycuronic acid also plays a part in the mechanism of the elimination of the sex hormones. These investigators succeeded in isolating and identifying œstriol glycuronide in an amorphous form (Marrian), and pregnandiol glycuronide in a crystalline condition (Venning and Browne), from pregnancy urine. The crystalline sodium salt of œstriol glycuronide proved to be about thirty times as weak as free œstriol on a subcutaneous injection into adult ovariectomized mice. Pregnandiol glycuronide was claimed by Venning and Browne to be the form in which progesterone is eliminated. The latter cannot couple, however, and must first of all be converted into the hydroxylated pregnandiol, within the organism. I wish to report here the synthetic preparation of the coupled glycuronic acids of dehydroandrosterone and of $\alpha$-œstradiol monobenzoate.

Methyl $\alpha$-acetobromoglyeuronate, prepared according to the directions of Goebel and Babers ${ }^{4}$, and the corresponding hormones, were the starting materials. When the synthesis was carried out in indifferent media, such as, for example, benzene in presence of silver carbonate, condensation took place with the elimination of bromine and the simultaneous formation of an oxygen bridge and the production of the corresponding derivative of the hormone glycuronide. Thus dehydroandrosterone furnished the acetylated glycuronide of the constitution shown in ( $\mathrm{I}$ ), as a welldefined, crystalline substance, m.p. 194-196 ${ }^{\circ}$ (uncorr.) $[\alpha]_{D}^{25^{\circ}}=-8 \cdot 4^{\circ}$ in chloroform.

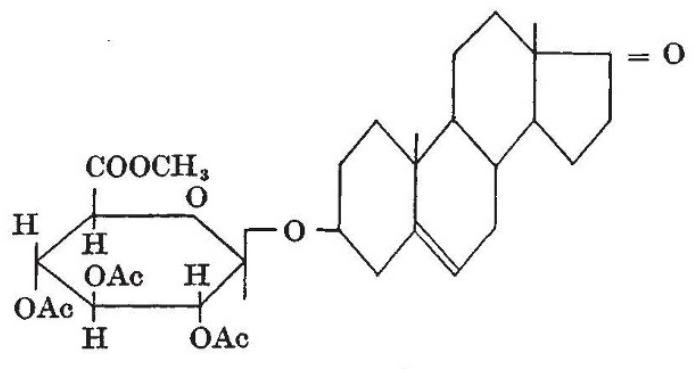

I<smiles>COC(=O)Oc1ccc2c(c1)CCC1C2CCC2(C)C(OCC3OCC(C(=O)O)C(O)C(O)C3OC(C)=O)CCC12</smiles>

II

$\alpha$-Estradiol benzoate afforded a similar, well-defined, crystalline substance, m.p. $189-191^{\circ}$ (uncorr.) with constitution shown in (Ir). This substance is optically inactive.

Hydrolysis with barium hydroxide in methyl alcoholic solution splits off the acetyl and the benzoyl as well as the methyl groups, with the production of the crystalline barium salts of the hormone glycuronide. The coupled hormone - glycuronic acids are obtained in glistening, mother-of-pearl-like scales by treating the barium salts with sulphuric acid.

(1) Dehydroandrosterone glycuronide melts at 262-264 $4^{\circ}$ (uncorr.), the colour turning brown and decomposition taking place.

(2) Estradiol (17)-glycuronide melts after shrinkage at $191-194^{\circ}$ (uncorr.) while the colour turns yellow and decomposition takes place.

On account of lack of material, the hormone glycuronides have not yet been obtained in an analytically pure state. They are fairly readily soluble in hot water.

The following preliminary data on the biological activity of the two preparations may be given. A daily dose of $20 \gamma$ of dehydroandrosterone glycuronide per capon dissolved in propylene glycol and smeared on the comb on each of four successive days was inactive. $77 \gamma$ per capon gave a sectional comb growth of 14 per cent after five days. $120 \gamma$ of œstradiol glycuronide, injected subcutaneously during 24 hours in three doses of $40 \gamma$, produced heat in castrated mice ; $12 \gamma$ was inactive. The considerable loss of activity of the substances in the form of a glycuronide compound is similar to that found by Marrian and collaborators for œstriol glycuronide.

We are now determining the physical constants of the analytically pure preparations and preparing other glycuronides.

\section{E. Schapiro.}

Pharmaco-therapeutical Laboratory,

University,

Amsterdam.

Oct. 3.

${ }^{2}$ Cohen, S. L., and Marrian, G. F., Biochem. J., 30, i, 57 (1936).

${ }^{2}$ Cohen, S. L., Marrian, G. F., and Odell, A. D., Biochem. J., 30, iv, 2250 (1936).

${ }^{3}$ Venning, E. M., and Browne, J. S., Proc. Soc. Exp. Biol. Med., 34, $792(1936)$

' Goebel, W. F., and Babers, F. H., J. Biol. Chem., 11, 347 (1935).

\section{Tyrosinase and Catechol Oxidase}

THE nature of tyrosinase has been under discussion for a very long time. Raper and his school ${ }^{1}$, Graubard and Nelson', and Keilin and Mann ${ }^{2}$ believe it to be a distinct enzyme, different from catechol oxidase. Onslow and Robinson ${ }^{4}$, McCance ${ }^{5}$, and Richter ${ }^{6}$ believe it to be a catechol oxidase plus 0 -chinone plus dehydrogenase. Kubowitz ${ }^{7}$, whose work appeared in a recent issue of the Biochemische Zeitschrift whilst we were preparing for publication our results, states that it is identical with catechol oxidase. Recent books ${ }^{8,9}$ appear to accept the first of these views.

The tyrosinase that we have worked with was extracted from Sepia. The action of the enzyme from this source has been shown by one of us $^{10}$ to be identical with that of Raper's mealworm tyrosinase. In agreement with most of the workers mentioned above, we have found that the partially purified tyrosinase acts on tyrosine with a very long induction period. This induction period can be reduced, as has long been known, by adding a trace of 0 -diphenol.

We have found that this 'activating effect' consists merely of the reduction of the induction period. After a short autocatalytic period, evidently depend. ing on the quantity of the o-diphenol added, the reaction in the two systems proceeds at equal speeds. 